\title{
Avaliação das potencialidades e limitações da trilha da Pedra Selada e dos percursos para a Pedra Boca do Sapo no Parque Estadual da Pedra Selada (RJ)
}

\author{
Evaluation of the potential and limitations of the Sealed \\ Stone trail and paths for the Pedra Boca do Sapo (Mouth \\ Frog Stone) in the 'Pedra Selada' (Sealed Stone) State Park \\ (RJ, Brazil)
}

Vítor José Corrêa e Ferreira

\begin{abstract}
RESUMO
O Parque Estadual da Pedra Selada, localizado no sul fluminense, possui atrativos turísticos muito interessantes, sendo o pico da Pedra Selada e os percursos para a Pedra Boca do Sapo, os mais conhecidos. Os objetivos do trabalho foram caracterizar e mapear as trilhas para localizar os pontos de limitações e os pontos de fragilidade ecoturística para auxiliar a gestão da Unidade de Conservação no planejamento, no manejo e na conservação da área. Para isso, foram mapeados com auxílio do GPS, os atrativos, os pontos de cicatrizes de erosão e na identificação das áreas sem manejo. $O$ geoprocessamento foi utilizado em conjunto com a metodologia do Índice de Atratividade de Pontos Interpretativos; o que permitiu localizar os pontos de fragilidade ecoturística. Esse estudo foi importante porque poderá contribuir com a Unidade de Conservação na implantação do Plano de Manejo e, auxiliar a gestão do Parque Estadual da Pedra Selada na preservação dos atrativos, podendo melhorar a visita dos turistas, a renda da população local e, principalmente, minimizar os impactos negativos na biota. Como principais resultados e conclusões, o presente trabalho contribuiu para auxiliar a gestão do Parque Estadual da Pedra Selada na identificação das áreas de baixa, média e alta fragilidade ecoturística; no diagnóstico antecipado das áreas que possam sofrer impactos causados pela visitação e contribuir também na implantação da zona de amortecimento da Unidade de Conservação na região da Pedra Boca do Sapo.

KEYWORDS: Parque Estadual da Pedra Selada; Fragilidade Ecoturística; Geoprocessamento.
\end{abstract}




\section{ABSTRACT}

The state Park off Pedra Selada, located on the south of Rio de Janeiro's state, has very interesting touristic attractions, one of them being the Pedra Selada and the paths to the Boca do Sapo Rock, those are the most famous ones. The focus of this study were characterize and map the trails to locate both the limitation and the vulnerability of those eco touristic spots it was done to assist management of the Conservation Unit on planning, forest management and conservation of the area. In order to do those attractions were mapped with the help off a GPS the spots of erosion scars and on the identification of areas without forest management. The geoprocessing was used in conjunction with the attractiveness Index methodology points Interpretive; what me possible to locate the vulnerable eco touristic. This study was important because it can contributes with the Conservation Unit at the implementation off the Forest management Plan and assist on the managing of the state Park off Pedra Selada preserving attractions making both the tourist visit and the income of the local population better and manly, minimize negative impacts on environment. As main result and conclusions, the study contributed to help management of the State Park off Pedra Selada identifying areas with low, medium and high vulnerability ecotourism; the early diagnosis of the areas that may suffer impacts due to visitation and also contribute to the establishment of the buffer zone of the Conservation Unit in the region of Boca do Sapo Rock.

KEYWORDS: 'Pedra Selada' State Park; Fragility Ecotourism; GIS.

\section{Introdução}

A prática do ecoturismo está tendo cada vez mais adeptos, e os locais mais procurados são as Unidades de Conservação. Este segmento do turismo se fundamenta, praticamente, em caminhadas por trilhas.

As trilhas provavelmente foram iniciadas por animais que se deslocavam para vários lugares. O homem pré-histórico começou a percorrer essas trilhas e abriram outras em busca de alimento e abrigo. (FOLMANN, 2010)

Nos dias de hoje, as trilhas proporcionam a prática de lazer na natureza, pois o cotidiano das pessoas nas grandes cidades está se tornando estressante.

Segundo Folmann (2010), as trilhas proporcionam a prática de lazer, além de oferecerem aos caminhantes, oportunidades de novas descobertas e percepções, tanto do local, como de si mesmo, ao possibilitarem a superação de obstáculos e limites.

Existem trilhas em praticamente todo o Território Nacional, principalmente nas Unidades de Conservação. As trilhas são essenciais para as áreas protegidas, pois são através delas que o visitante ou o pesquisador passa a percorrer determinadas distâncias até um atrativo ou uma área de pesquisa.

Muitas das vezes, a própria trilha se torna um atrativo, por conter em seu percurso, por exemplo, a presença de espécies endêmicas de flora, mirantes, rastros de fauna, riachos, quedas d'água e a presença ou o canto dos pássaros. 
Porém, se as trilhas não forem planejadas e houver carência de fiscalização e monitoramento, poderão ocorrer impactos ambientais tanto nas trilhas, quanto na Unidade de Conservação.

Isso é reforçado por (MAGANHOTO 2009, p. 13) "a implantação de trilhas de forma desordenada e sem planejamento pode contribuir para 0 desencadeamento de impactos, potencializados pelo não entendimento da dinâmica física de um local. Além disso, a carência de monitoramento e manutenção são fatores determinantes à conservação destes ambientes".

Segundo (LECHNER 2006, p. 13), "as trilhas costumam ser o primeiro dos elementos de infraestrutura desenvolvidas sempre que uma nova área protegida é declarada e, com frequência, isso ocorre antes que o planejamento formal ou mesmo um Plano de Manejo sejam implantados".

Com um planejamento adequado, as trilhas podem se tornar ferramentas para a educação ambiental.

Folmann (2010) cita que as trilhas interpretativas têm um importante papel a desenvolver, pois são os meios mais propícios à disseminação da educação ambiental.

Sendo assim, as trilhas estão diretamente ligadas ao ecoturismo, pois proporcionam ao visitante um contato direto com a natureza.

Segundo (SILVA et. al. 2008), o ecoturismo é visto como o turismo responsável, no qual o visitante está ciente e leva em conta os efeitos de suas ações sobre a cultura e o ambiente local.

O ecoturismo responsável é uma ferramenta muito importante para o desenvolvimento de educação ambiental.

O ecoturismo, "entendido como instrumento de educação ambiental, pode contribuir para a construção de representações e significados no imaginário social e transformar a relação do ser humano com o ambiente. $A$ percepção edênica dos destinos ecoturísticos, carregada de simbolismo, remete seus aspectos à busca de um ideal de paisagem onde a ética e a estética tem papel de destaque". (COSTA et. al., 2008, p. 44)

Folmann (op. cit, p. 23), cita que "as trilhas de interpretação da natureza são caminhos existentes estabelecidos, com diferentes formas, comprimentos e larguras, que possuam o objetivo de aproximar o visitante do ambiente natural, ou conduzi-lo a um atrativo específico, possibilitando seu entretenimento ou educação através de sinalizações ou de recursos interpretativos".

No caso do Parque Estadual da Pedra Selada (PEPS), que se localiza na Serra da Mantiqueira, nos municípios de Resende e Itatiaia, a trilha que leva ao cume, que recebe o mesmo nome do Parque, é frequentada por visitantes e isso pode acarretar inúmeros problemas ambientais, sendo importante um diagnóstico para descobrir e localizar pontos de erosão e pontos potenciais de beleza cênica de acordo com o tipo de trilha, fazendo com que o local possa ser acessado por turistas / visitantes, minimizando os impactos ambientais, em consonância com que preceitua o ecoturismo.

A Pedra Boca do Sapo ainda não possui uma trilha oficial, mas existem duas formas para acessar o cume. Esse percurso que já é utilizado 
se inicia dentro de uma propriedade particular; e o percurso opcional se inicia num curral às margens da rodovia RJ-151.

Esse atrativo não se localiza dentro dos limites do PEPS, porém, segundo a administração do Parque, há um grande interesse de incorporar essa região nas delimitações da área protegida, podendo ser incorporada ao Plano de Manejo.

Nesse sentido, o objetivo geral da presente dissertação é, a partir do diagnóstico físico e ambiental das trilhas da Pedra Selada e Pedra Boca do Sapo, identificar suas potencialidades e limitações à visitação, considerando o crescente interesse pela região, por parte de visitantes e turistas e a ausência de uma avaliação detalhada do uso público que conduza de forma correta, as práticas de lazer e recreação no interior e periferia próxima da área protegida.

Para se atingir o objetivo geral, os objetivos específicos são: (a) caracterizar e mapear, com o auxílio do geoprocessamento, os aspectos físico-bióticos das trilhas selecionadas; (b) aplicar a metodologia que permita avaliar as fragilidades ecoturísticas e limitações encontradas em seu percurso (c) e propor ações de manejo que possam garantir o desenvolvimento do ecoturismo nas trilhas.

\section{Caracterização da área de estudo com destaque para as trilhas selecionadas}

As trilhas selecionadas fazem parte do circuito de trilhas do Parque Estadual da Pedra Selada e de seu entorno próximo, a seguir resumidamente descritos.

\section{O Parque Estadual da Pedra Selada}

O Parque Estadual da Pedra Selada (PEPS) se localiza no Médio Vale do Paraíba no Estado do Rio de Janeiro, na serra da Mantiqueira, abrangendo os municípios de Resende e Itatiaia.

O Parque foi criado recentemente pelo Decreto Estadual no 43.640 de 15 de junho de 2012. Inicialmente, a proposta para a área do PEPS somava 8.400 hectares (ha). Após consulta pública, realizada em 7 de dezembro de 2011, e de mais dois encontros realizados em 2012 com a comunidade interessada, a proposta de limites do PEPS foi redefinida, reduzindo sua área para cerca de 8.000 ha. Por solicitação da prefeitura de Resende, uma área de 36 ha, próxima a Visconde de Mauá, onde estava prevista a criação de um parque municipal, foi incorporada à Unidade Estadual. Portanto, a área total do PEPS é de 8.036 ha, segundo a Cartilha $n^{\circ} 1$ Abrindo os Caminhos, do Parque Estadual da Pedra Selada, produzida pelo Instituto Estadual do Ambiente (INEA).

\section{Trilhas selecionadas: localização e sua importância na implementação do uso público no PEPS}

As trilhas foram selecionadas de acordo com a importância dentro da Unidade de Conservação: a trilha da Pedra Selada se localiza dentro da Unidade de Conservação e os percursos que levam à Pedra Boca do Sapo 
(Figura 1) localizam-se na área de entorno, sendo as mais visitadas da área protegida e área de entorno.

\section{A trilha da Pedra Selada}

A trilha que leva ao cume da Pedra Selada possui um percurso de subida de $2.265 \mathrm{~m}$ até o cume e inicia na vertente norte da Serra da Mantiqueira, na altitude de $1.085 \mathrm{~m}$, no distrito de Visconde de Mauá próximo à rodovia RJ - 151, nas coordenadas UTM 556140m e 7535157m.

O nível de dificuldade do percurso para se chegar até a entrada da trilha é baixo, podendo-se chegar de carro.

A trilha inicia em uma propriedade particular na área de pastagem, a uma altitude de $1.085 \mathrm{~m}$. Partir de $895 \mathrm{~m}$ de distância, se localiza os limites do PEPS, a uma altitude de $1.231 \mathrm{~m}$, seguindo até a distância de $2.319 \mathrm{~m}$, quando a mata dá lugar às rochas à mostra, que segue até o cume a $1.768 \mathrm{~m}$ de altitude (Figura 2), nas coordenadas UTM 557174m e 7534198m, num percurso total de $2.265 \mathrm{~m}$.

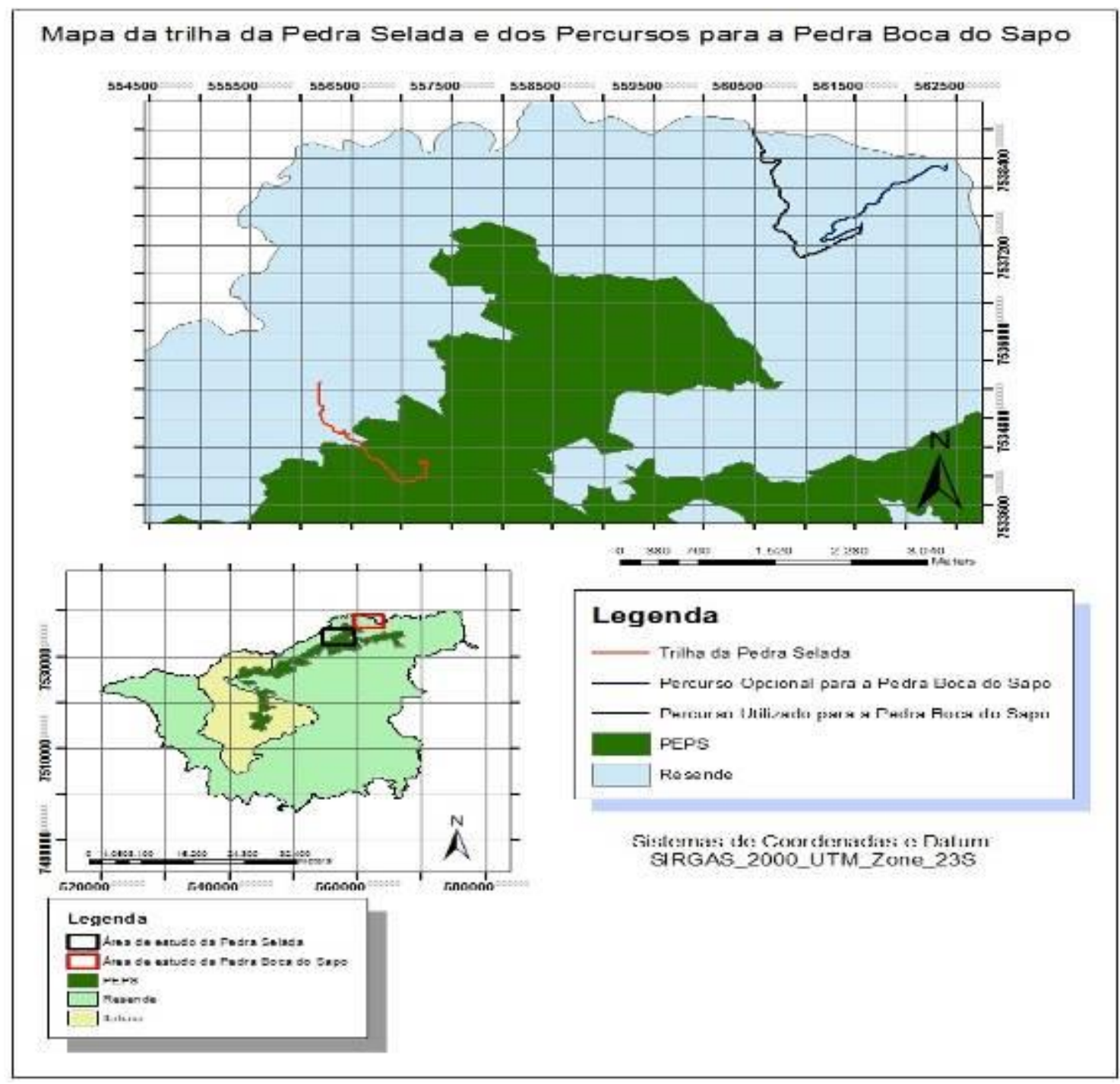

Figura 1: Mapa de localização das áreas de estudo. Fonte: O autor (2014), baseado nos arquivos adquiridos do INEA e mapeamento por GPS.

Figure 1: Location of the study area map. Source: The author (2014), based in Files Bought do INEA and GPS FOR Mapping. 


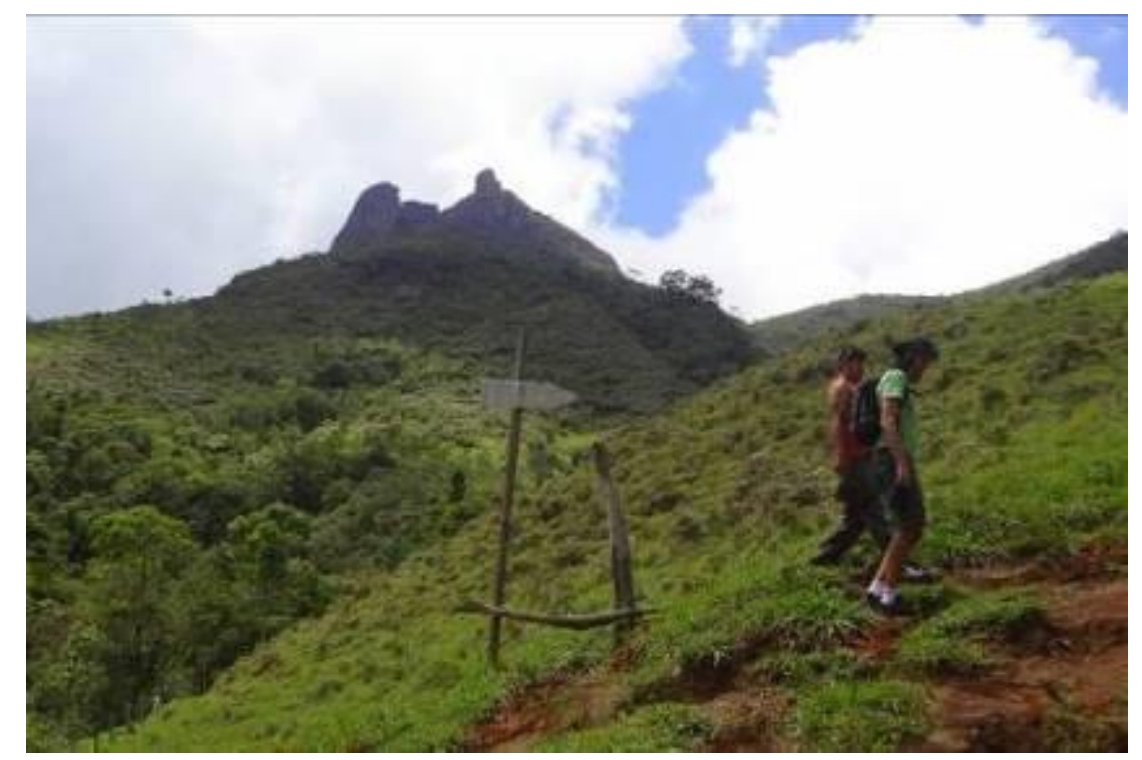

Figura 2: Trecho inicial da trilha da Pedra Selada. Fonte: O autor (2013). Figure 2: Initial stretch of track Sealed Stone. Source: The author (2013).

\section{Trilhas para a Pedra Boca do Sapo}

A Pedra Boca do Sapo ainda não possui uma trilha oficial. Porém, existem dois caminhos para se chegar ao cume. O percurso mais utilizado inicia em uma propriedade particular próxima à rodovia $\mathrm{RJ}-151$; no distrito de Visconde de Mauá, município de Resende, nas proximidades da ponte que faz a divisa de Estado do Rio de Janeiro com Minas Gerais, denominada "Ponte do Souza".

O outro percurso se inicia num curral que se localiza também às margens da rodovia RJ - 151.

Esse percurso utilizado se iniciou nas coordenadas UTM 560904m e $7538633 \mathrm{~m}$, numa altitude de $981 \mathrm{~m}$, nas proximidades do Parque Estadual da Pedra Selada, com uma extensão de $3.138 \mathrm{~m}$ até o cume, que está a uma altitude de $1.367 \mathrm{~m}$.

A maior parte do percurso é realizada em regiões de pastagem possuindo um comprimento de $1.745 \mathrm{~m}$ até adentrar na mata a uma altitude de $1.315 \mathrm{~m}$. $1.393 \mathrm{~m}$.

O percurso por dentro da mata até o cume tem o comprimento de

Ao final da trilha, próxima ao cume, há uma bifurcação onde se inicia um caminho que leva à parte inferior do maciço, onde há uma abertura nas rochas que segue até chegar a um platô, com uma altitude de 1368m (Figura $3)$. 


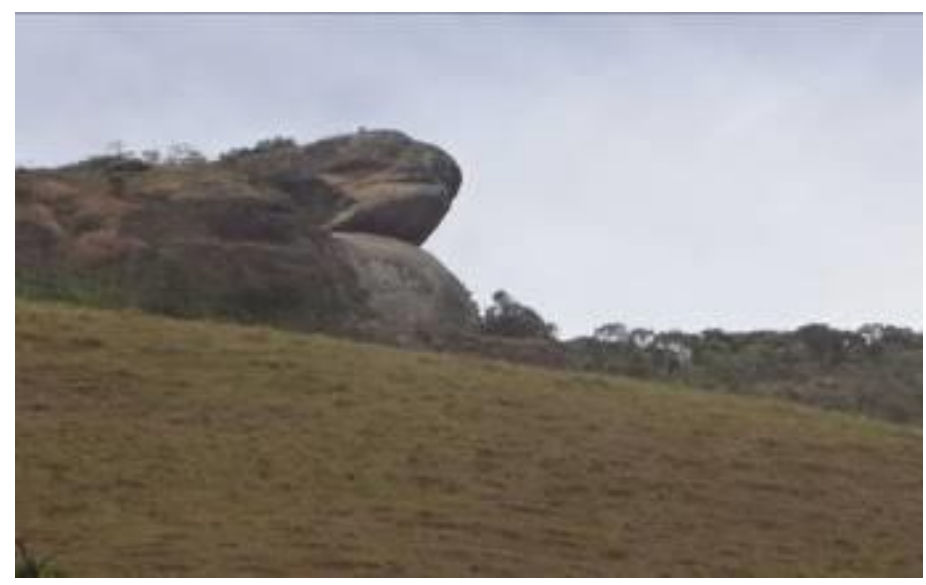

Figura 3: Vista para a Pedra Boca do Sapo. Fonte: O autor (2014).

Figure 3: Frog Mouth Stone view. Source: The author (2014).

No sentido leste da bifurcação, o percurso tem cerca de $10 \mathrm{~m}$ até chegar ao cume da Pedra Boca do Sapo, na altitude de $1.375 \mathrm{~m}$.

O percurso opcional também possui grande parte do trajeto em regiões de pastagem, adentrando à mata quase no cume.

O início do percurso opcional se localiza num curral às margens da rodovia RJ - 151, nas coordenadas UTM 562420m e 7538305m.

Este caminho possui um trajeto menor que o utilizado anteriormente, com $2.539 \mathrm{~m}$, possuindo pontos com potencial para a interpretação ambiental, e áreas para descanso (Figura 4).

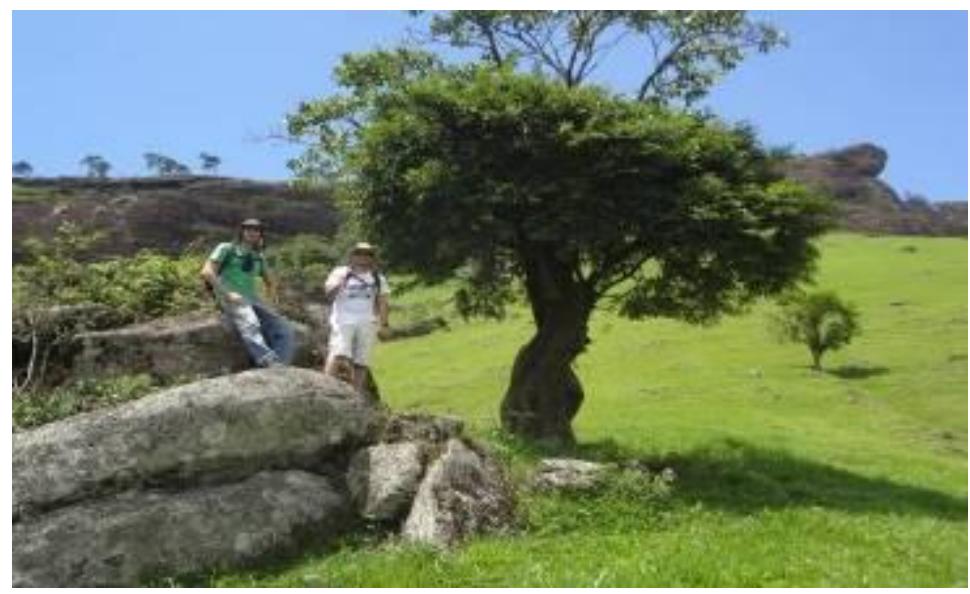

Figura 4: Ponto com potencial para a interpretação ambiental. Fonte: O autor (2014).

Figure 4: With potential point for environmental interpretation. Source: The author (2014).

\section{Materiais e métodos}

No desenvolvimento do presente estudo, utilizou-se o GPS Garmin etrex 10 para o mapeamento do traçado das trilhas, atrativos, pontos sem manejo e mapas de cicatrizes de erosão. Todos os mapeamentos foram realizados nas coordenadas UTM.

Todos os dados do GPS foram utilizados no estudo do geoprocessamento para a confecção dos mapas básicos. 


\section{Geoprocessamento}

Os mapas básicos foram adquiridos através de websites governamentais em formato shape.

Os mapas de Geologia foram adquiridos do Centro de Pesquisa de Recursos Minerais (CPRM). Os mapas de Geomorfologia, Uso e Cobertura da Terra (UCT) e Cotas Altimétricas foram adquiridos do Instituto Estadual do Ambiente. O mapa de Solos foi adquirido da Empresa Brasileira de Pesquisa Agropecuária (EMBRAPA).

Após a aquisição dos respectivos mapas, foram recortadas a área de estudo da Pedra Selada e a área de estudo da Pedra Boca do Sapo.

Também foi adquirido em formato Raster, a Carta Topográfica do Município de Resende para a vetorização dos rios, riachos, córregos e vias de acesso das respectivas áreas de estudo.

Após a aquisição desses mapas, foram produzidos no Laboratório de Geoprocessamento da UERJ (LAGEPRO), com o auxílio do software ArcGis 10.1, os mapas de Declividade.

Para a confecção dos mapas de Declividade, foram utilizados os Modelos Digitais de Elevação (MDE). Os MDE's foram importantes, no presente estudo, pois através deles foi possível delimitar corretamente os divisores de água, sendo significativo para estudos ligados à modelagem ambiental, conforme afirma (CECÍLIO 2013, p. 1008)

(CECÍLIO op cit), destaca ainda que os MDE's são aplicativos computacionais de SIGs, que realizam procedimentos automáticos, por meio de algoritmos que identificam divisores de água a partir de uma representação matricial da topografia do terreno.

Os MDE's são obtidos através da interpolação de dados topográficos pontuais e de curvas de nível extraídas de cartas topográficas, ou através de imagens de sensoriamento remoto.

Os interpoladores são ferramentas encontradas em SIG's, utilizadas em "técnicas para se estimar o valor de uma determinada grandeza a partir de um conjunto de amostras. A interpolação é necessária quando se deseja inferir valores em localizações particulares entre os pontos amostrados". (OLIVEIRA, 2010, p. 416).

(CECÍLIO 2013, p. 2008) ressalta que "atualmente os Modelos Digitais de Elevação são obtidos por meio de imagens de sensores remotos (radares) ou da interpolação de dados topográficos pontuais e curvas de nível extraídas de cartas topográficas ou levantamentos planaltimétricos".

No presente estudo, o ArcGis 10.1 é um SIG que possui dois interpoladores: Topo to Raster - TR; e o Triangulated Irregular Network - TIN. (CECÍLIO, 2013 p. 2010).

O TIN, segundo (COSTA 2006, p. 125) "é a estrutura de dados que descreve uma superfície tridimensional como uma série de triângulos adjacentes formados de maneira irregular".

O interpolador Topo to Raster - TR é um método criado para a criação de MDEs hidrologicamente corretos e consegue representar as mudanças abruptas dos terrenos, como rios e cumes. 
O Topo to Raster é um método projetado especificamente para a criação de MDEs hidrologicamente corretos, originado no programa ANUDEM da The Australian National University, e também disponibilizado no ArcGis. O algoritmo de interpolação mescla a eficiência computacional dos métodos de interpolação locais (como o inverso do quadrado da distância) com a continuidade da superfície de métodos de interpolação globais, como a krigagem e o spline discretizada, que permite representar mudanças abruptas do terreno como os rios e os cumes (OLIVEIRA, 2010, p. 417).

O presente estudo usou o interpolador TR para garantir que os resultados fossem mais precisos. Um estudo realizado na Bacia Hidrográfica do Rio da Prata, inserida na bacia hidrográfica do rio Itapemirim, no Estado do Espírito Santo, por Cecílio (2013), constatou que o interpolador TR obteve melhores resultados que o interpolador TIN, tanto em estudos nas áreas de drenagem, quanto nos estudos de bacia hidrográfica.

Os intervalos das classes de declividade (Tabela 1) utilizados foram definidos a partir da metodologia aplicada por (COSTA, 2006) nos estudos de trilhas realizadas no Parque Estadual da Pedra Branca, que cita "as características do relevo como parâmetros norteadores das classes de declividade" (COSTA, 2006, p. 127).

Após a confecção dos mapas citados, foram confeccionados os mapas de proximidade (Buffers) sendo definida uma distância de 50 metros para as trilhas, rios, riachos, córregos e vias de acesso; e um raio de 50 metros para os Mapas de proximidade dos atrativos, pontos sem manejo e cicatrizes de erosão.

Tabela 1: Intervalos de classificação de declividade considerando as características do relevo.

Table 1: classification slope intervals considering the relief features.

\begin{tabular}{|c|c|c|}
\hline $\begin{array}{l}\text { Intervalo de } \\
\text { declive ( \%) }\end{array}$ & $\begin{array}{l}\text { Classe de } \\
\text { Declividade }\end{array}$ & Caracterização \\
\hline$<3 \%$ & $\begin{array}{l}\text { Relevo Plano - } \\
\text { encosta sem } \\
\text { problemas }\end{array}$ & $\begin{array}{l}\text { Superfície de topografia esbatida ou horizontal, onde os } \\
\text { desnivelamentos são muito pequenos. }\end{array}$ \\
\hline $3 \%-8 \%$ & $\begin{array}{l}\text { Relevo Suave } \\
\text { Ondulado }\end{array}$ & $\begin{array}{l}\text { Superfície de topografia pouco movimentada, constituída } \\
\text { por conjunto de colinas e/ou outeiros, apresentando } \\
\text { declives suaves. }\end{array}$ \\
\hline $8 \%-20 \%$ & Relevo Ondulado & $\begin{array}{c}\text { Superfície de topografia pouco movimentada, constituída } \\
\text { por conjunto de colinas e/ou outeiros, apresentando } \\
\text { declives acentuados. }\end{array}$ \\
\hline $20 \%-45 \%$ & $\begin{array}{l}\text { Relevo Fortemente } \\
\text { Ondulado }\end{array}$ & $\begin{array}{l}\text { Superfície de topografia movimentada, formada por } \\
\text { outeiros e/ou morros, com declives fortes. }\end{array}$ \\
\hline $45 \%-100 \%$ & $\begin{array}{l}\text { Relevo Montanhoso e } \\
\text { Escarpado }\end{array}$ & $\begin{array}{l}\text { Superfície de topografia vigorosa, com predomínio de } \\
\text { formas acidentadas, usualmente constituída por morros, } \\
\text { montanhas e maciços montanhosos e alinhamentos } \\
\text { montanhosos, apresentando desnivelamentos } \\
\text { relativamente grandes e declives fortes e muito fortes, } \\
\text { com vales encaixados. }\end{array}$ \\
\hline
\end{tabular}

Fonte: Elaborado por Costa (2006, p. 127).

Source: Prepared by Costa ( 2006, p 127). 


\section{Aplicação do Método de Indicadores de Avaliação de Pontos Interpretativos - IAPI}

Existem métodos de estudo em trilhas que levam em consideração o potencial que o local possui para o trabalho de interpretação ambiental. Dentre os métodos utilizados, o que se aplica melhor ao presente estudo é o método de Indicadores de Atratividade de Pontos Interpretativos - IAPI.

Tal método, segundo (MAGRO 1998, p. 5), "contribui para um melhor planejamento de trilhas com um impacto positivo ao visitante, pois leva em consideração, não apenas o elemento principal em questão, mas também outros atributos chamados de indicadores".

(OLIVEIRA 2010, p. 63), explica que o IAPI auxilia no levantamento de informações que "permitem definir aspectos que podem ser melhorados na trilha, a fim de gerar informações úteis na elaboração de um programa para a melhoria da infraestrutura".

Segundo (MAGRO 1998, p. 5), o método "objetiva agregar ao potencial interpretativo, um valor qualitativo para aumentar a atratividade do local".

O método do IAPI é dividido em cinco fases:

A Primeira fase consiste no levantamento de pontos potenciais de informação no percurso da trilha. Para esse processo, é necessária a utilização de um GPS e máquina fotográfica para registrar e selecionar.

$\mathrm{Na}$ segunda fase a observação da paisagem é importante para o levantamento de indicadores em diferentes pontos potenciais, levando em consideração "a distribuição espacial dos elementos e o horizonte de visada" (OLIVEIRA, 2010).

A terceira fase é referente à elaboração da ficha de campo de acordo com o levantamento dos indicadores nos pontos potenciais.

A quinta e última fase consiste na contagem de pontos que foram registrados na ficha de campo dos locais de interesse ecológico de forma definitiva, após uma conferência final em campo.

A partir do cálculo do IAPI, pode-se atribuir valores aos atrativos das áreas de estudo. Os valores então são introduzidos no geoprocessamento para classificar e localizar os pontos com maiores ou menores atratividades.

Para a elaboração da ficha de campo, utilizou-se o mesmo modelo utilizado por (COSTA 2006). O modelo foi escolhido por ser considerado o mais completo dentre os modelos encontrados, atendendo as necessidades das áreas de estudo do presente trabalho.

O objetivo é registrar os pontos com potencialidades ecoturísticas em todo o percurso, com o intuito de valorizar os atrativos do local, auxiliar as autoridades competentes na gestão das trilhas e incentivar a Educação Ambiental para turistas e moradores.

Os pontos foram marcados nas fichas de campo (Quadro 1) na medida em que foram surgindo ao longo da trilha, sem necessariamente manter certa equidistância. 
Quadro 1: Ficha de Campo da Trilha da Pedra Selada.

Frame 1: Field Data Sheet Trail of Sealed Stone.

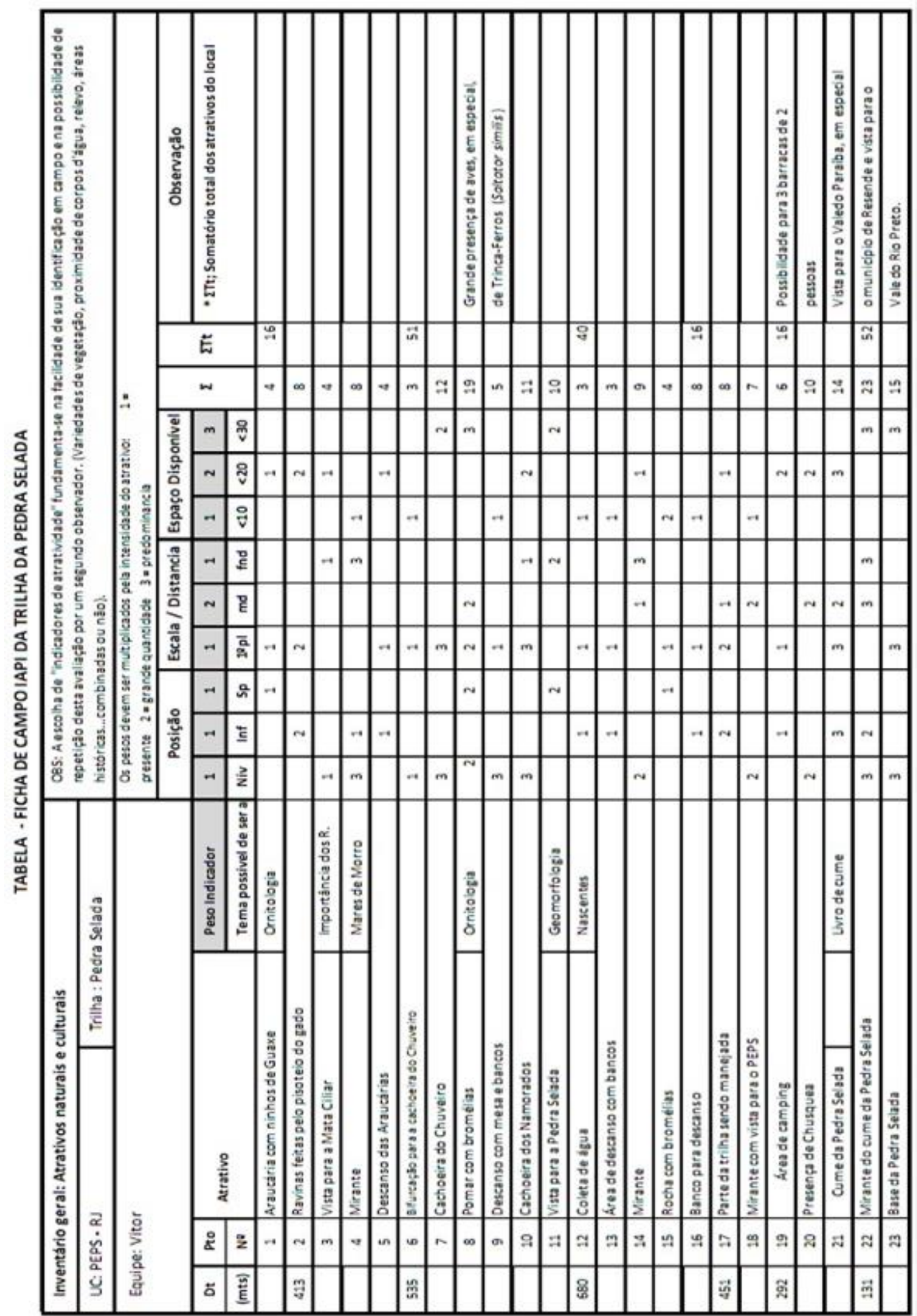

Fonte: O autor (2014), baseado no modelo de Costa (2006).

Source: The author (2014), based in Costa (2006) model. 


\section{Mapas Analíticos}

A partir dos mapas básicos produzidos no presente estudo, foram confeccionados os mapas analíticos de vulnerabilidade erosiva, mapas de fatores limitantes e mapas de fragilidades ecoturísticas.

$\mathrm{Na}$ confecção dos mapas de vulnerabilidade erosiva da trilha da Pedra Selada e Pedra Boca do Sapo, realizou-se a análise multicritério, sendo utilizada a álgebra Overlay, na qual utiliza sobreposições de mapas usando uma escala de mesma medida comum e pesos, cada um com sua importância. Foram utilizadas nas análises os mapas das áreas de influência das trilhas, mapas de geomorfologia, geologia, solos, uso e cobertura da terra e os mapas de declividade com os pesos e porcentagens.

Para a confecção do mapa de vulnerabilidade, os mapas de geomorfologia, geologia, solos e UCT, foram recortados de acordo com o mapa de influência dos respectivos percursos da Pedra Boca do Sapo e da trilha da Pedra Selada.

A partir de então, os mapas foram sendo classificados com pesos e porcentagens de acordo com suas características.

Nos mapas de geomorfologia, considerou-se a porcentagem de $25 \%$ de influência na produção dos mapas de vulnerabilidade, porque o relevo de Serras Escarpadas é considerado muito acidentado, o que pode acentuar nos processos erosivos.

Os mapas de declividade são considerados de grande importância, pois, segundo (COSTA 2006, p. 123), "a altitude e o gradiente das encostas são parâmetros importantes no desencadeamento de impactos sobre os solos".

Sabendo-se dessa importância, foi considerado porcentagem de 30\% para os mapas de declividade.

Os mapas de solos têm relevância porque dependendo do tipo de solo no leito e margens das trilhas, estes podem ser mais ou menos susceptíveis a erosão.

Constatou-se que os percursos para a Pedra Boca do Sapo e da trilha da Pedra Selada possuem o mesmo solo, o Cambissolo.

Em geral, esses solos são de alta vulnerabilidade erosiva. Devido a essa relevância, considerou-se a porcentagem de $25 \%$.

Nos mapas de Uso e Cobertura da Terra, considerou-se a porcentagem de $15 \%$, porque grande parte da trilha da Pedra Selada se localiza dentro dos limites da Unidade de Conservação e os percursos para a Pedra Boca do Sapo se localizam na área de entorno, tendo um monitoramento contínuo da gestão do PEPS.

Através dos mapas de geologia constatou-se que toda a trilha da Pedra Selada e dos percursos da Pedra Boca do Sapo possuem formações de gnaisses e granito.

Para os mapas de geologia foi considerado a porcentagem de 5\%. 
Considerou-se a importância de cada mapa para a adequação dos pesos, que variam de 1 a 9.

Nos mapas de geomorfologia, utilizou-se o peso 7 pelo relevo ser classificado com Serras Escarpadas.

Nos mapas de declividade, os pesos foram adequados de acordo com o Intervalo de declive em percentual, conforme a Tabela 2.

Tabela 2: Relevâncias das classes de declividade.

Table 2: Relevances of slope classes.

\begin{tabular}{cc} 
Intervalos de Declive em Percentual & Pesos \\
$>3 \%$ & 1 \\
$3 \%-8 \%$ & 3 \\
\hline $8 \%-20 \%$ & 5 \\
\hline $20 \%-45 \%$ & 7 \\
\hline $45 \%-100 \%$ & 9
\end{tabular}

Fonte: O autor (2015), baseado na tabela de Intervalos de declive em Percentual.

Source: The author (2015), based on the slope table Percentage intervals

Nos mapas de UCT, foram considerados os tipos pastagem e floresta.

As regiões de pastagem foram classificadas com peso 5, por deixarem os solos mais expostos às intempéries, enquanto as regiões de floresta foram classificadas com peso 1.

Os mapas de solos foram classificados com peso 7 devido a presença de apenas um tipo de solo, o Cambissolo.

Os mapas de geologia receberam dois pesos. Peso 1 para as formações de gnaisses e peso 2 para as formações graníticas.

No percurso utilizado para a Pedra Boca do Sapo, foi constatado a presença de depósitos aluvionares, sendo classificados com o peso 3.

Para a produção dos mapas de fatores limitantes utilizou-se os mapas de vulnerabilidade erosiva, os mapas de cicatrizes de erosão, os mapas de áreas em manejo e os mapas das áreas de influência.

$\mathrm{Na}$ trilha da Pedra Selada constatou-se que todos os pontos que possam limitar o acesso localizam-se em áreas de Alta Vulnerabilidade, conforme demonstra a Figura 5. 


\section{Fatores limitantes da trilha da Pedra Selada}

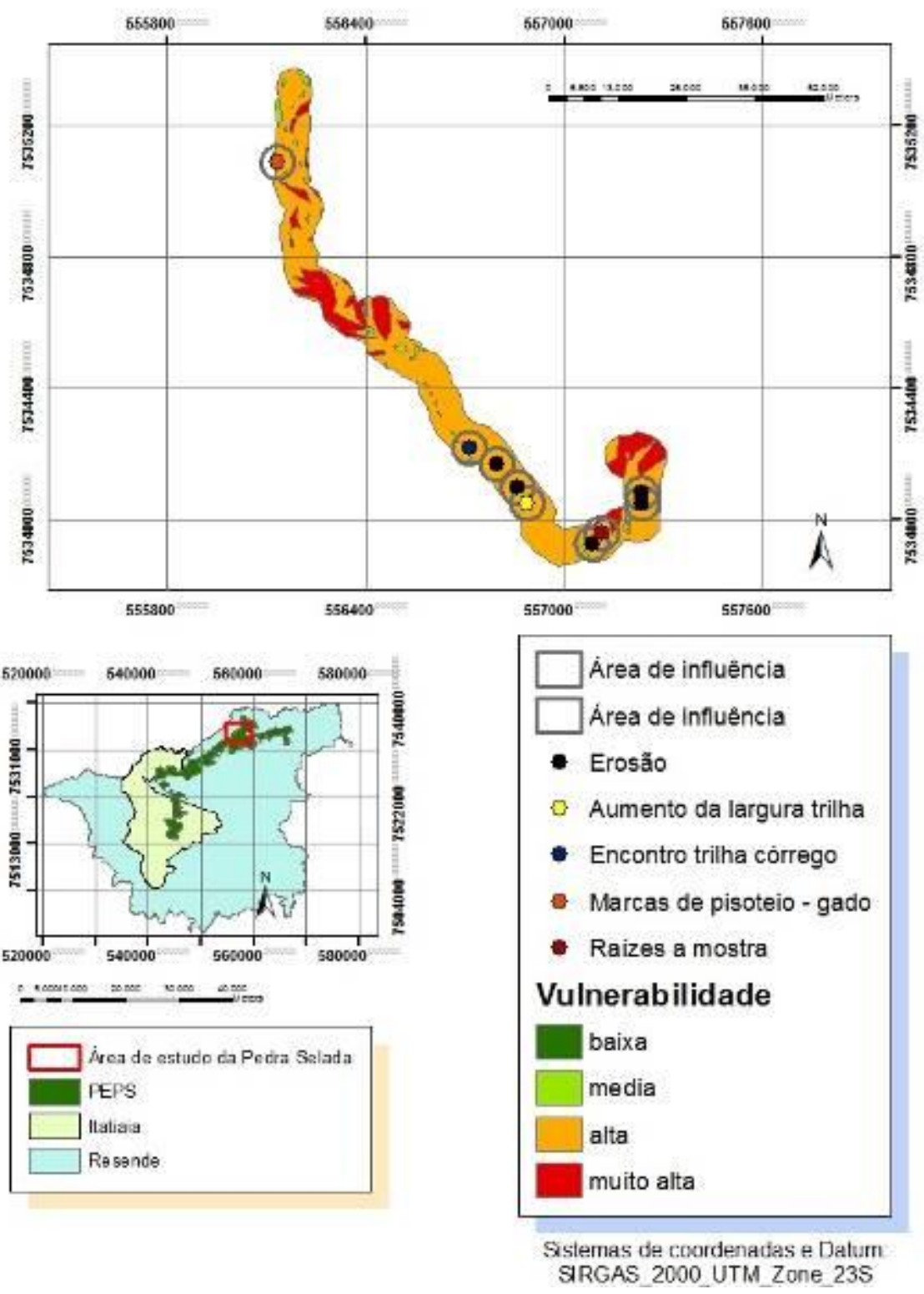

Figura 5: Mapa dos fatores limitantes da trilha da Pedra Selada. Fonte: O autor (2015), baseado nos mapas de vulnerabilidade erosiva, áreas sem manejo, cicatrizes de erosão e áreas de influência da trilha da Pedra Selada.

Figure 5: Map of the limiting factors of the track Sealed Stone. Source: The author (2015), based on erosive vulnerability maps, unmanaged areas, erosion scars and areas of influence of track Sealed Stone

Constatou-se que $88,8 \%$ dos pontos se localizam em regiões de Alta vulnerabilidade e $11,1 \%$ se localizam em áreas de Média vulnerabilidade (Tabela 3), no percurso utilizado para a Pedra Boca do Sapo (Figura 6). 
Tabela 3: Fatores Limitantes do percurso utilizado.

Table 3: Limiting Factors of the route.

\begin{tabular}{llc} 
Vulnerabilidade & Fatores Limitantes & Percentual \\
\hline Média Vulnerabilidade & Arame farpado & $11,1 \%$ \\
\hline & Arame farpado & \\
& Vestígios de incêndio & \\
& Vestígios de incêndio & \\
Alta Vulnerabilidade & Vestígios de incêndio & $88,8 \%$ \\
& Vestígios de incêndio & \\
& Vestígios de incêndio & \\
& Vestígios de incêndio & \\
& Vestígios de incêndio
\end{tabular}

Fonte: O autor (2015), baseado no mapa de fatores limitantes do percurso utilizado da Pedra Boca do Sapo.

Source: The author (2015), based on the map of limiting factors of the route Stone Mouth Frog.

Fatores limitantes do percurso utilizado para a Pedra Boca do Sapo
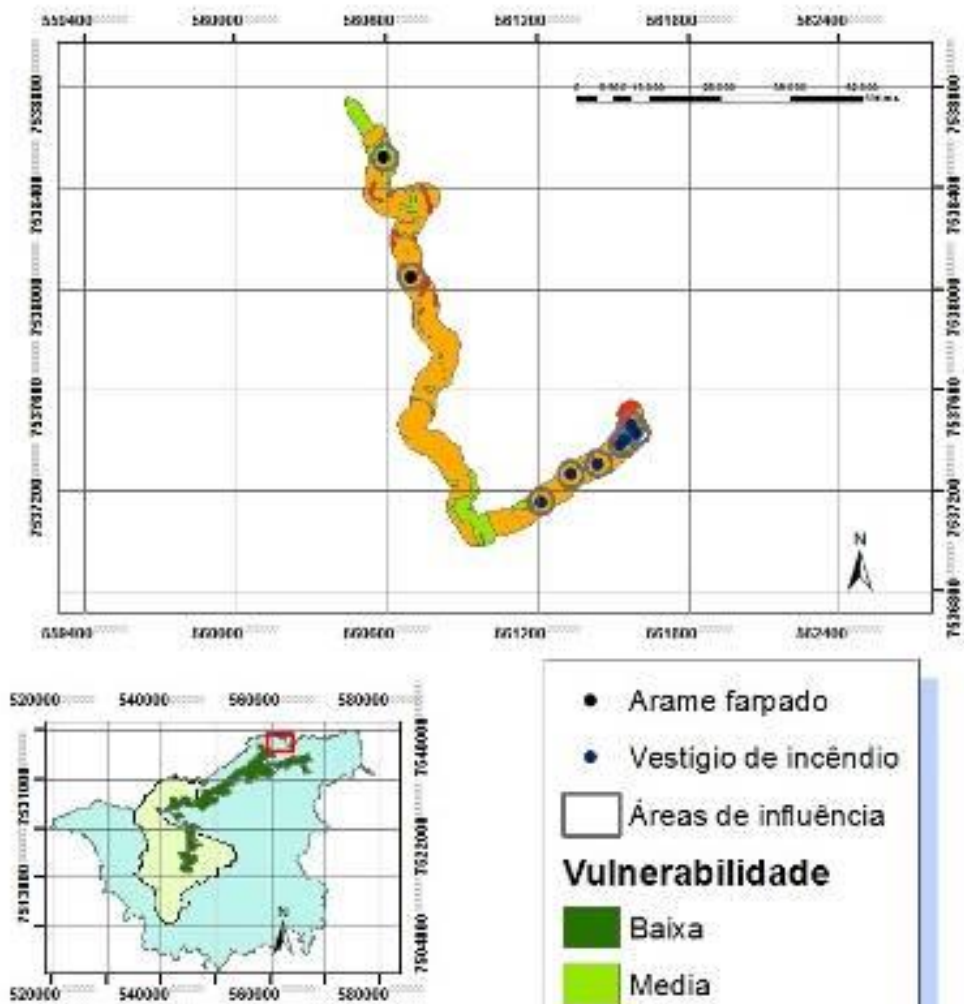

- Arame farpado

- Vestigio de incêndio Areas de influencia Vulnerabilidade

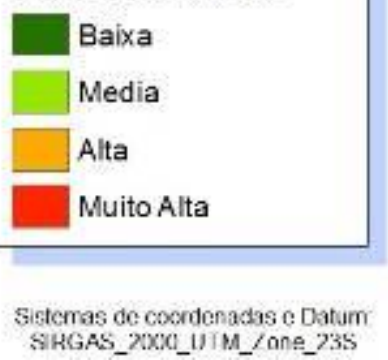

Figura 6: Mapa dos fatores limitantes do percurso utilizado da Pedra. Fonte: $O$ autor (2015), baseado no mapa de vulnerabilidade erosiva, mapa de cicatrizes de erosão e mapa de áreas sem manejo do percurso utilizado da Pedra Boca do Sapo.

Figure 6: Map of the limiting factors of the route Stone. Source: The author (2015), based on erosive vulnerability map, erosion scars map and map areas without management of the route Stone Mouth Frog. 
O mapa de fatores limitantes do percurso opcional (Figura 7, próxima página) demonstrou que os atrativos estão distribuídos por todo o percurso, mas $41,6 \%$ dos pontos de limitação localizam-se em áreas com Alta vulnerabilidade erosiva, outros $41,6 \%$, em áreas de vulnerabilidade Muito Alta e apenas $16,6 \%$, localizam-se em áreas de Média vulnerabilidade (Tabela 4).

Tabela 4: Fatores Limitantes do percurso opcional.

Table 4: Limiting Factors optional route.

\begin{tabular}{|c|c|c|}
\hline Vulnerabilidade & Fatores Limitantes & Percentual \\
\hline Média Vulnerabilidade & $\begin{array}{l}\text { Voçoroca } \\
\text { Vestígio de incêndio }\end{array}$ & $16,6 \%$ \\
\hline Alta Vulnerabilidade & $\begin{array}{c}\text { Erosão } \\
\text { Voçoroca } \\
\text { Voçoroca } \\
\text { Vestígios de incêndio } \\
\text { Vestígios de incêndio }\end{array}$ & $41,6 \%$ \\
\hline Muito Alta Vulnerabilidade & $\begin{array}{l}\text { Vestígios de incêndio } \\
\text { Vestígios de incêndio } \\
\text { Vestígios de incêndio } \\
\text { Vestígios de incêndio } \\
\text { Vestígios de incêndio }\end{array}$ & $41,6 \%$ \\
\hline
\end{tabular}

Source: The author (2015), based on the map of actors limiting the optional route Stone Mouth Frog.

Para a produção dos mapas de fragilidade ecoturística, realizou-se a sobreposição dos mapas de vulnerabilidade erosiva, os mapas de atrativos e os mapas das áreas de influência dos atrativos.

Dependendo da localização dos atrativos, são identificados os pontos com maior ou menor vulnerabilidade erosiva.

A utilização do método IAPI foi importante porque através do somatório dos pesos dados a cada atrativo, foi possível localizar as áreas com maior atratividade. Quanto maior for o somatório dos pesos, maior será sua importância, isto é, maior será sua atratividade.

Identificando os pontos com maior atratividade no mapa de vulnerabilidade erosiva, podem-se localizar as áreas de Fragilidade Ecoturística e classificá-las (Tabela 5). 
Fatores limitantes do percurso opcional para a Pedra Boca do Sapo

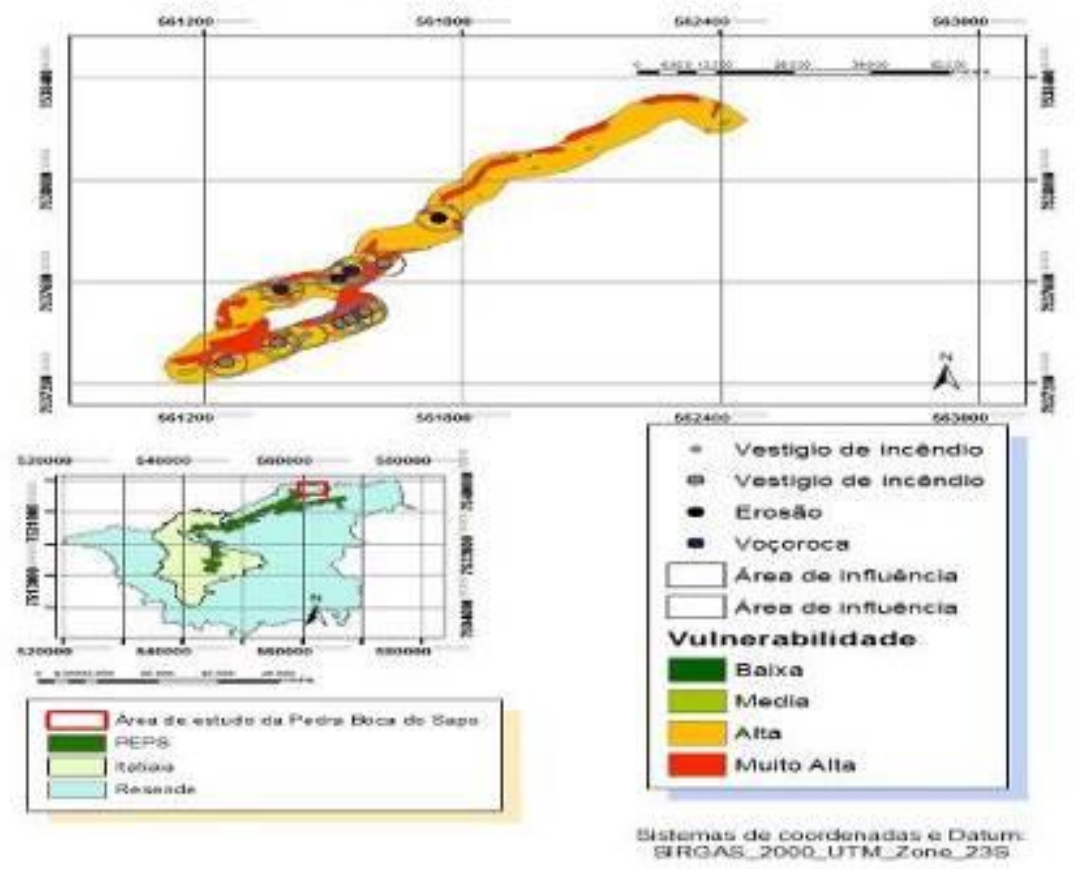

Figura 7: Mapa de fatores limitantes do percurso opcional da Pedra Boca do Sapo.

Fonte: O autor (2015), baseado no mapa de vulnerabilidade erosiva, mapa de cicatrizes de erosão e mapa de áreas sem manejo do percurso do opcional da Pedra Boca do Sapo.

Figure 7: Map of the factors limiting optional route Stone Mouth Frog. Source: The author (2015), based on erosive vulnerability map, map of erosion scars and map areas without optional path management Stone Mouth Frog.

Tabela 5: Classes de fragilidade ecoturísticas.

Table 5: Ecotouristic fragility classes.

\begin{tabular}{ll} 
Classes & Descrição \\
\hline Baixa Fragilidade & $\begin{array}{l}\text { Atrativos localizados em áreas com Vulnerabilidade baixa e } \\
\text { Atratividade baixa, média ou alta. }\end{array}$ \\
\hline Média Fragilidade & $\begin{array}{l}\text { Atrativos localizados em áreas com Vulnerabilidade alta ou média e } \\
\text { Atratividade baixa ou média. }\end{array}$ \\
\hline Alta Fragilidade & $\begin{array}{l}\text { Atrativos localizados em áreas com vulnerabilidade Alta ou Muito Alta } \\
\text { e Atratividade média ou alta. }\end{array}$ \\
\hline
\end{tabular}

Fonte: O autor (2015).

Source: The author (2015)

$\mathrm{Na}$ confecção do mapa de fragilidade ecoturística da trilha da Pedra Selada (Figura 8), utilizou-se o mapa de atrativos com os cálculos obtidos a partir do método IAPI e classificados em: Baixa, Média e Alta Atratividade. A partir daí os pontos de atratividade foram sobrepostos ao mapa de vulnerabilidade erosiva (Tabela 6). 


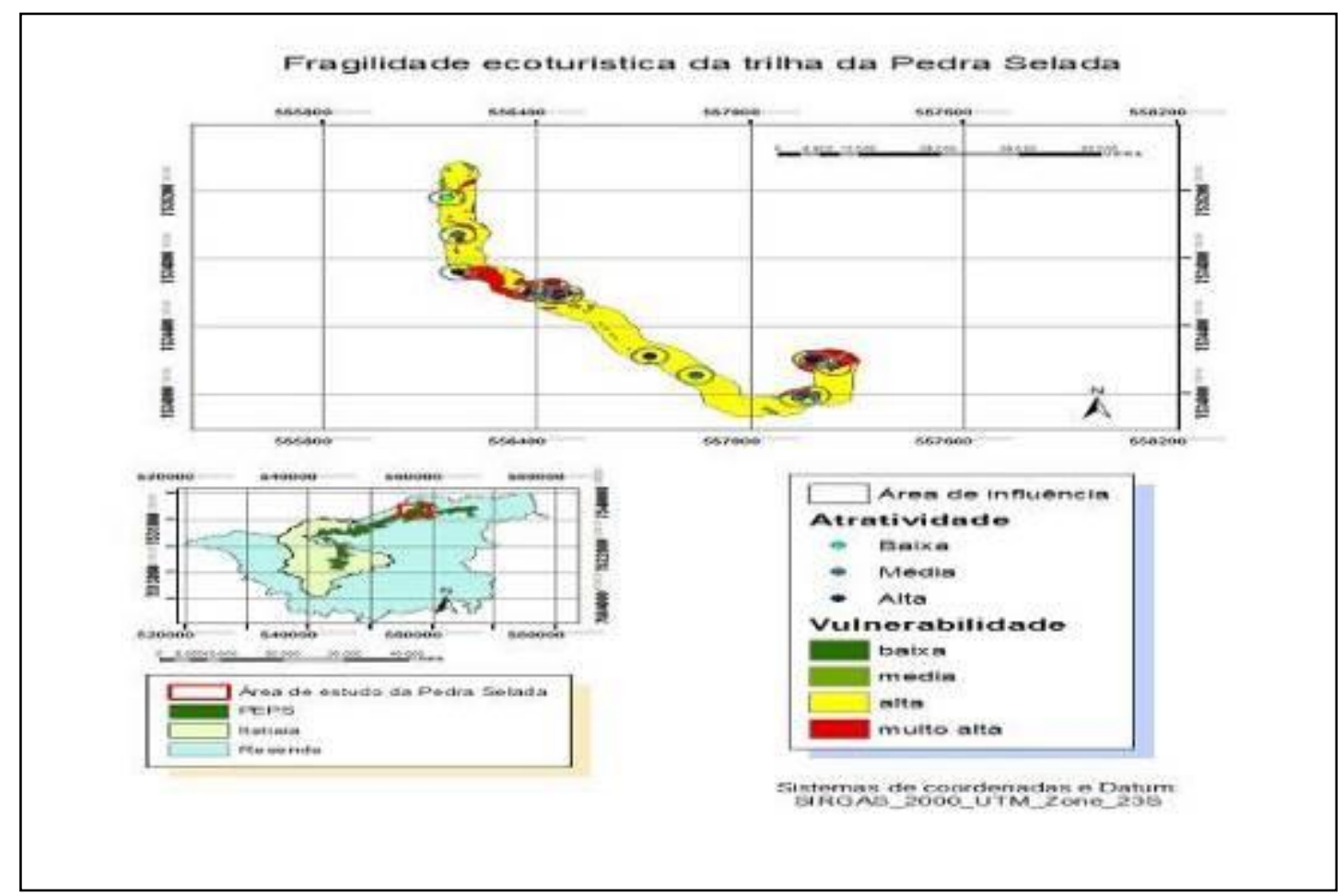

Figura 8: Mapa de fragilidade ecoturística da trilha da Pedra Selada. Fonte: O autor (2015), baseado no mapa de vulnerabilidade erosiva e mapa de atrativos da Pedra Selada.

Figure 8: Ecotouristic fragile Map of Track Sealed Stone. Source: The author (2015), based on erosive vulnerability map and map of attractions of the Sealed Stone.

De acordo com a análise, constatou-se que, de acordo com a Tabela de Fragilidade Ecoturística, 7,1\% dos atrativos da trilha da Pedra Selada foram classificados como Média Fragilidade, e 92,8\% dos atrativos foram classificados como de Alta Fragilidade (Tabela 6).

Tabela 6: Classes de fragilidade ecoturística da trilha da Pedra Selada. Table 6: Ecoturistic fragility classes of Track Sealed Stone.

\begin{tabular}{lll}
\hline Classes de Fragilidade & Atrativos & Percentual \\
\hline Baixa fragilidade & --- & --- \\
\hline Média fragilidade & 1 & $7,1 \%$ \\
\hline Alta fragilidade & 13 & $92,8 \%$ \\
\hline
\end{tabular}

Fonte: O autor (2015), baseado no mapa de fragilidade ecoturística da trilha da Pedra Selada. Source: The author (2015), based on ecotouristic fragility of the map Track Sealed Stone.

No mapa de fragilidade ecoturística do percurso utilizado (Figura 9), também foi utilizado o mapa de atrativos com os respectivos pesos do cálculo em campo do IAPI. Em seguida foi sobreposto ao mapa de vulnerabilidade. 
Fragilidade ecoturistica da trilha da Pedra Selada
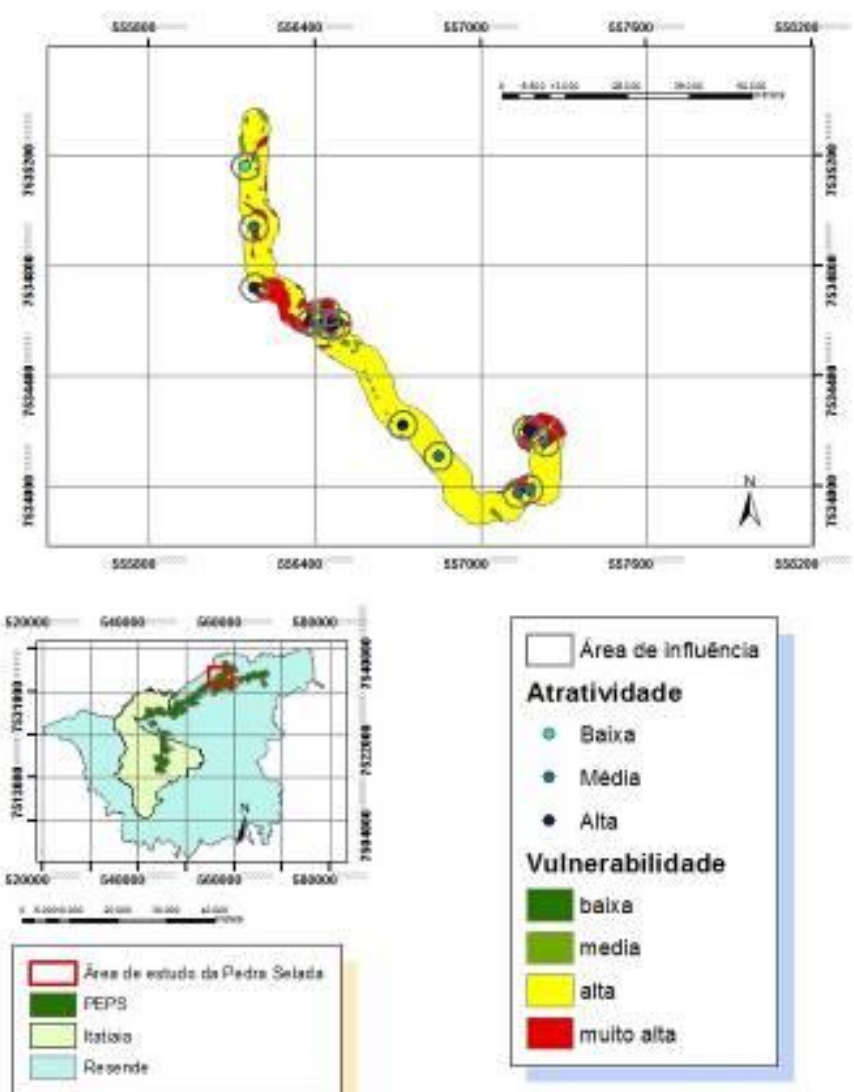

Sisternas de coondenadas e Datum

Sisternas da coordenadas e Datun
SARGAS 2000 UTM Zane 23S

Figura 9: Mapa de fragilidade ecoturística do percurso utilizado. Fonte: $O$ autor (2015), baseado no mapa de vulnerabilidade erosiva e mapa de atrativos do percurso utilizado da Pedra Boca do Sapo.

Figure 9: Ecotouristic fragility map of the route. Source: The author (2015), based on erosive vulnerability map and used the attractive route map Stone Mouth Frog.

De acordo com o mapa de fragilidade ecoturística do percurso utilizado, constatou-se que $90 \%$ dos atrativos são de Alta Fragilidade e apenas 10\% são atrativos de Média Fragilidade (Tabela 7).

Tabela 7: Classes de fragilidade ecoturística do percurso utilizado.

Table 7: Classes ecotouristic fragility of the route.

\begin{tabular}{lcc}
\hline Classes de fragilidade & Atrativos & Percentual \\
\hline Baixa Fragilidade & --- & --- \\
\hline Média Fragilidade & 1 & $10 \%$ \\
\hline Alta Fragilidade & 9 & $90 \%$ \\
\hline
\end{tabular}

Fonte: $O$ autor (2015), baseado no mapa de fragilidade ecoturística do percurso utilizado para a Pedra Boca do Sapo.

Source: The author (2015), based on ecotouristic fragility map of the route for the Stone Mouth Frog,

No mapa de fragilidade ecoturística do percurso utilizado (Figura 10), também foi utilizado o mapa de atrativos com os respectivos cálculos em 
campo do método IAPI. Em seguida foi sobreposto ao mapa de vulnerabilidade.

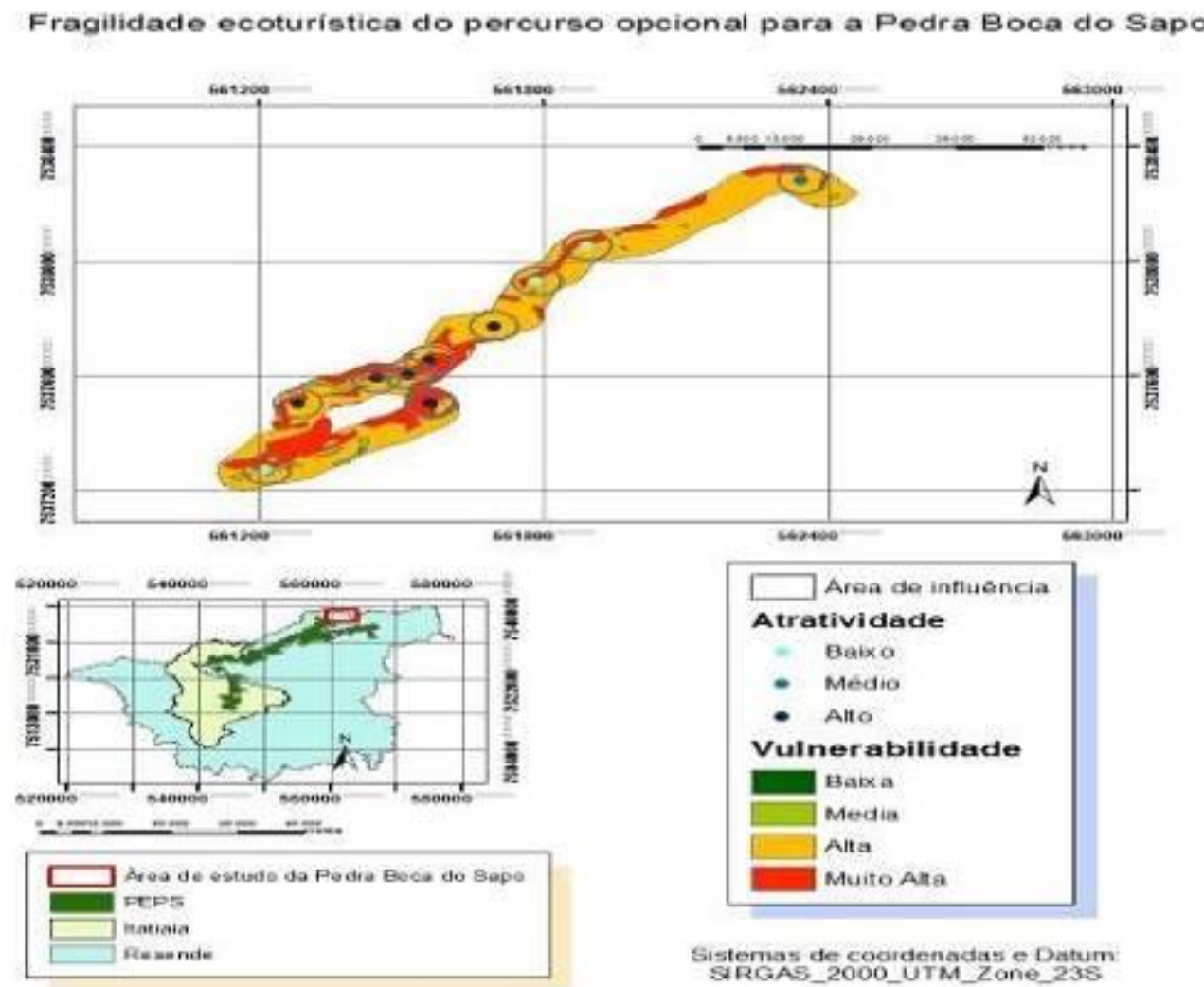

Figura 10: Mapa de fragilidade ecoturística do percurso opcional da Pedra Boca do Sapo. Fonte: O autor (2015), baseado no mapa de vulnerabilidade erosiva e mapa de atrativos do percurso opcional da Pedra Boca do Sapo.

Figure 10: ecotouristic fragile Map optional route Stone Mouth Frog. Source: The author (2015), based on erosive vulnerability map and the optional route map attractive stone Mouth Frog.

De acordo com os resultados obtidos, constatou-se que um atrativo se localiza em uma área de média vulnerabilidade, porém, possui uma alta vulnerabilidade, classificando-o como uma área de Alta Fragilidade.

De acordo com o mapa de fragilidade ecoturística do percurso opcional, foi constatado que todos os atrativos foram classificados como sendo de Alta Fragilidade (Tabela 8).

Tabela 8: Classes de declividade do percurso opcional.

Table 8: Optional route slope classes.

$\begin{array}{ccc}\text { Classes de fragilidade } & \text { Atrativos } & \text { Percentual } \\ \text { Alta Fragilidade } & 11 & 100 \%\end{array}$

Fonte: O autor (2015), baseado no mapa de fragilidade ecoturística do percurso opcional para a Pedra Boca do Sapo.

Source: The author (2015), based on ecotouristic fragility map optional route for Mouth Frog Stone. 


\section{Conclusões e considerações finais}

O PEPS possui atrativos turísticos com alto potencial à Educação Ambiental e ao Ecoturismo, sendo o pico da Pedra Selada o mais conhecido.

Por se localizar numa região de grande fluxo de turistas, essa região da Unidade de Conservação recebe muitos visitantes para frequentarem as trilhas da região.

Como o Plano de Manejo ainda está sendo implantado, o presente trabalho visou contribuir com o estudo de Fragilidades Ecoturísticas na trilha da Pedra Selada e nos percursos que levam à Pedra Boca do Sapo.

A utilização do método do IAPI foi de grande relevância, pois foi possível localizar e calcular através de pesos, os atrativos mais importantes das áreas de estudo, dando-Ihes uma classificação de alta, média e baixa atratividade. Esse estudo em campo foi crucial para a produção dos mapas de fragilidades ecoturísticas, pois, juntamente com os mapas de vulnerabilidade erosiva, foram encontrados os locais com diferentes níveis de fragilidade ecoturística.

O estudo realizado foi importante, pois localizou os pontos em que a vulnerabilidade erosiva pode atuar negativamente na qualidade da visita, nos riscos que os visitantes e o ecossistema possam vir a sofrer, e principalmente, na preservação das trilhas e seus atrativos.

O diagnóstico das fragilidades ecoturísticas e dos fatores limitantes à visitação na trilha da Pedra Selada e nos percursos para a Pedra Boca do Sapo levaram à proposição do aproveitamento e conservação de seus atrativos.

A utilização do geoprocessamento no presente estudo foi de grande importância, pois conseguiu identificar alguns pontos importantes de monitoramento nas trilhas que não são perceptíveis em campo.

Com os dados que foram fornecidos pelo SIG, a gestão da Unidade de Conservação pode intensificar os trabalhos de manejo nas áreas com cicatrizes de erosão e, principalmente, propor ações de conservação utilizando a Educação Ambiental nas áreas que foram localizadas e identificadas com fragilidades ecoturísticas alta e muito alta.

Na região da Pedra Boca do Sapo foi considerado que o atrativo ainda não possui uma trilha oficial e o geoprocessamento auxiliou na hierarquização dos dois percursos estudados, dando uma oportunidade às autoridades competentes a um estudo mais detalhado da área para uma futura escolha de percurso, podendo contribuir para a definição de uma trilha oficial que cause menos impactos negativos e propor ações de conservação na área tornando-se importante tanto para visitantes, quanto para a população local, além de auxiliar na implantação da Zona de Amortecimento do PEPS.

Nessa área, que não se localizada dentro dos limites do PEPS, há a necessidade de entrar em acordo com o proprietário da área particular para a troca dos arames por portões ou tronqueiras. 
As autoridades competentes poderiam aproveitar a área que foi queimada para realizar o balizamento da trilha antes que a vegetação cresça novamente, além de programas de reflorestamento e combate a incêndios.

O percurso opcional possui pontos com muita atratividade, porém há áreas que necessitam atenção das autoridades competentes, como as áreas onde localizam as voçorocas, pois o percurso tende a passar muito próximo, podendo agravar a situação.

Devido à gravidade dos processos erosivos, é preferível continuar com o trabalho no percurso utilizado até serem contidos o aumento das voçorocas.

Outro ponto importante no presente estudo é que a gestão do PEPS pode identificar antecipadamente, os pontos que possam vir a ser uma limitação à visitação, e, dessa forma, atuar antes desses pontos se tornarem críticos à visitação e a degradação ambiental do local.

O estudo se tornou interessante para a gestão do Parque Estadual da Pedra Selada, pois, os trabalhos de manejo das trilhas devem ter um cunho de prevenção, porque, os trabalhos de manejo de recuperação demandam mais tempo, mais trabalho, mais funcionários, e, consequentemente, mais despesas.

\section{Referências bibliográficas}

CECÍLIO, R. A., Delimitação de bacia hidrográfica em região montanhosa a partir de diferentes modelos digitais de elevação. Seminário: Ciências Agrárias, Londrina, v. 34, n. 5, 2007.

COSTA, N.M.C.; NEIMAN, Z.; COSTA, V.C. Pelas trilhas do ecoturismo. São Carlos: Rima, 2008.

COSTA, N.M.C. et al. Fragilidade ecoturísitca em áreas de atrativos no Parque Estadual da Pedra Branca (RJ). Geo UERJ, Rio de Janeiro, v.2, n. 19 p. $138,2009$.

COSTA, V.C. Propostas de manejo e planejamento ambiental de trilhas ecoturísticas: um estudo no maciço da Pedra Branca-município do Rio de Janeiro -. 2006. Tese (Doutorado em Ciências) - Instituto de Geografia, Universidade Federal do Rio de janeiro, Rio de Janeiro, 2006.

CPRM

Disponível

em: $<$ http://geobank.cprm.gov.br/pls/publico/geobank.download.downloadVetoriai s?p webmap=N\&p usuario=1> Acesso em: 20 jan. 2015.

EMBRAPA - Disponível em:

$<$ http://www.agencia.cnptia.embrapa.br/gestor/solos tropicais/arvore/CONTA G01 8 2212200611538.html.> Acesso em: 21 mar. 2015.

EMBRATUR - Disponível em:

$<$ http://www.turismo.gov.br/turismo/programas acoes/regionalizacao turism o/estruturacao segmentos/ecoturismo.html>. Acesso em: 05 mar. 2014. 
FOLMANN, A.C. Trilhas interpretativas como instrumentos de geoturismo e geoconservação: caso da trilha do Salto São Jorge, nos Campos Gerais do Paraná. 2010. Dissertação (Mestrado em Gestão do Território) Universidade Estadual de Ponta Grossa, Ponta Grossa, 2010.

INEA - Disponível em:

$<$ http://www.inea.ri.gov.br/Portal/MegaDropDown/EstudosePublicacoes/Publi caes/EstadodoAmbiente/index.html> Acesso em: 06 set. 2014.

LECHNER, L. Planejamento, implantação e manejo de trilhas em Unidades de Conservação. Curitiba: Fundação $O$ Boticário de proteção à natureza, 2006.

MAGANHOTO, R.F. et al. Planejamento de trilhas em áreas naturais estudo de caso Sítio da Alegria, Prudentópolis/Guarapuava - PR. Revista Geografar, v.4, n.2, p. 143-163, 2009.

MAGRO, T. C. Impactos do uso público em uma trilha no Planalto do Parque Nacional do Itatiaia. 1999. Tese (Doutorado em Ciências da Engenharia Ambiental) - Universidade de São Carlos, São Carlos, 1999.

OLIVEIRA, G. G. Espacialização e análise das inundações na bacia hidrográfica do rio Caí / RS. Geociências, UNESP, v. 29, n. 3, p. 413, 2010.

SILVA, C. E. et al. Ecoturismo na Floresta Nacional do Ibura como potencial fomento de sociedades sustentáveis. Revista Nordestina de Ecoturismo, v. 1, n. 1, p. 6-17, 2008.

\section{Agradecimento}

O presente artigo é derivado da dissertação apresentada ao Programa de Pósgraduação em Geografia (PPGEO) da Universidade do Estado do Rio de Janeiro. Agradeço primeiramente a meus pais e à Vanessa pela paciência e compreensão. À Orientadora Prof(a). Dra. Nadja Maria Castilho da Costa pela ajuda, dedicação e paciência. Aos bolsistas do Laboratório de Geoprocessamento da UERJ (LAGEPRO): Evelyn Meirelles e Wilson Messias, ao Diretor do Parque Estadual da Pedra Selada, Rodrigo Rodrigues e aos funcionários da Unidade de Conservação. Ao Grupo Excursionista Agulhas Negras, pela inspiração, e ao presidente, Agenor Maia Siqueira. Também agradeço à "Tia Lena"pelo carinho, atenção e receptividade. E aos amigos que me acompanharam no trabalho de campo, Robson Alex Xingu e Felipe Aulis.

Vítor Correa Ferreira: Universidade Estado do Rio de Janeiro, Rio de Janeiro, RJ, Brasil.

E-mail: vj_correa@yahoo.com.br

Link para o currículo Lattes: http://lattes.cnpq.br/8960678949566940

Data de submissão: 09 de setembro de 2015

Data de recebimento de correções: 19 de outubro de 2015

Data do aceite: 19 de outubro de 2015

Avaliado anonimamente 